\title{
Physicochemical effects of long-term deposition of sewage sludge on Brazilian Oxisol
}

\author{
M. M. Yada ${ }^{1}$, F. L. C. Mingotte ${ }^{1}$, W. J. de Melo ${ }^{1}$, V. P. de Melo ${ }^{2}$, \\ G. M. P. de $\mathrm{Melo}^{2}$ \& U. C. M. Proença ${ }^{3}$ \\ ${ }^{1}$ Departamento de Tecnologia, Universidade Estadual Paulista, Brazil \\ ${ }^{2}$ Universidade Camilo Castelo Branco, Brazil \\ ${ }^{3}$ Faculdade de Tecnologia, Brazil
}

\begin{abstract}
The aim of this work was to evaluate the effect of doses of sewage sludge (SS) when applied for sixteen consecutive years to the Brazilian Oxisols Typic Haplothox (sandy) and Typic Eutrorthox (clayey), on the chemical characteristics of soil fertility. The experiment was carried out in a field at Jaboticabal, SP, Brazil, using experimental design in randomized blocks with 4 treatments and 5 replications. Sewage sludge was applied on soil surface and incorporated at the $0-10 \mathrm{~cm}$ depth with a light harrow. Sixty days after SS application, soil samples were collected at the depth 0-20 cm (10 simple samples per plot, which were mixed to obtain a composite sample). The treatments were $\mathrm{T} 1=$ no SS and mineral fertilization based on soil chemical analysis, T2 $=5 \mathrm{t}$

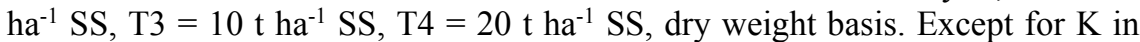
the Typic Eutrothox, the amendment of the soils did not affect soil fertility that was considered as middle fertility, and also did not affect maize grain production. The lack of effect of SS on soil fertility and plant production is attributed to the water deficit in the period between the SS incorporation and the soil sampling. The doses $10 \mathrm{t} \mathrm{ha}^{-1} \mathrm{SS}$ increased $\mathrm{K}$ in the Typic Eutrorthox, probably due to $\mathrm{K}$ extraction from the soil organic matter. In all the treatments, the bases saturation was below the recommended for maize, that is $70 \%$. Maize fertilized with $5 \mathrm{t} \mathrm{ha}^{-1}$ sewage sludge, dry weight basis, plus $\mathrm{K}$, produced the same that the mineral fertilization.
\end{abstract}

Keywords: biosolid, soil fertility, maize, pollution. 


\section{Introduction}

Sewage sludge (SS) is a solid residue obtained in the wastewater treatment [1]. It is a heterogeneous material whose composition varies according to the origin of the sewer, i.e. from domestic or industrial areas, the period of the year and the social condition of the population [2].

The volume of sewage produced, expressed in liters per habitant per day, is affected by several factors such as climate, population size and economic situation, degree of industrialization of the area, measurement of water service, availability and cost of treated water etc. [3].

The growth of urban areas has caused social, economic and environmental problems as the generation of residues whose disposition has not been made adequately. The domestic residues are actually one of the great environmental problems, including SS. It has been estimated that $50 \%$ of the cost of treating wastewater is due to the disposition of the residue, which varies according to the disposition option [4].

The SS composition is closely related to the sociocultural status of the population since the chemical characteristics of the wastewater depend on factors such as consumption pattern, basic sanitation, industrial development, wastewater treatment process and quality of the SS produced $[5,6]$.

Application of SS in the soil may affect both the chemical composition related to soil fertility as well as those that cause a negative impact on soil, as the increase in trace elements concentration, phosphorus fixation and loss of nitrogen through ammonia volatilization. It may also contaminate surface and ground waters with nitrate, phosphate, trace elements and other possible pollutants.

The Brazilian SS production in 2011 was about 150-220 thousand tons per year, and that production is increasing with the increase in the sewer collection [7], which may cause a severe environmental problem if viable social, economic and environmental disposition methods for the residue are not developed [8].

The application of $67.5 \mathrm{t} \mathrm{ha}^{-1} \mathrm{SS}$ in six successive years $\left(2.5 \mathrm{t} \mathrm{ha}^{-1}\right.$ during three years and $30 \mathrm{t} \mathrm{ha}^{-1}$ during the other three years) caused a grain production of $8.6 \mathrm{t} \mathrm{ha}^{-1}$ against $5.6 \mathrm{t} \mathrm{ha}^{-1}$ when chemical fertilization was used [9]. This positive effect of SS on maize grain production was also observed by other authors [8].

\section{Methodology}

The aim of this work was to evaluate chemical properties of two Brazilian Oxisols amended with rates of SS after sixteen annual applications of the residue.

The experiment was carried out under field conditions at Jaboticabal, São Paulo State, Brazil (21 15 '22” SE $48^{\circ} 15^{\prime} 18^{\prime}$ ' W) in two types of soils, a Typic Haplorthox (TH, sandy), and a Typic Eutrorthox (TE, clayey).

This experiment was started in 1996 and this work presents the data collected in the season year 2012/2013. 
The experimental design was randomized blocks with four treatments (rates of SS) with five replications using plots with $60 \mathrm{~m}^{2}(6 \times 10 \mathrm{~m})$.

In the season year 2012/2013 the treatments were 0 (control with no SS and mineral fertilization based on soil chemical analysis), 5, 10 and $20 \mathrm{t} \mathrm{ha}^{-1} \mathrm{SS}$, dry weight basis. Sewage sludge was supplied by the Wastewater Treatment Station operated by SABESP (Companhia de Saneamento Básico do Estado de São Paulo S.A) situated in Monte Alto, São Paulo State, Brazil.

The authors proceeded to the preparation of the area, through the application of herbicide. The application of SS to the soil was taken in November 2012, the start of the rainy period. The SS applied to the plots was distributed manually and incorporated into $10 \mathrm{~cm}$ depth with a light harrow. The soil was furrowed (90 $\mathrm{cm}$ between furrows), the mineral fertilizers were disposed into the furrows and maize (transgenic hybrid resistant to pests) was sowed.

The mineral fertilization in the treatments is shown in table 1.

Table 1: Mineral fertilization applied to the treatments.

\begin{tabular}{lcccc}
\hline \multirow{2}{*}{ Fertilizer } & \multicolumn{4}{c}{ Treatments $\left(\mathrm{t} \mathrm{ha}^{-1}\right)$} \\
\cline { 2 - 5 } $\mathrm{N}$ & Control & \multicolumn{4}{c}{10} & 20 \\
\hline $\mathrm{P}_{2} \mathrm{O}_{5}$ & 30 & \multicolumn{2}{c}{ Sowing $\left(\mathrm{kg} \mathrm{ha}^{-1}\right)$} & -- \\
$\mathrm{K}_{2} \mathrm{O}$ & 50 & -- & -- & -- \\
& 50 & -- & -- & -- \\
$\mathrm{N}$ & & 36 & 22 & - \\
$\mathrm{P}_{2} \mathrm{O}_{5}$ & 140 & 40 days after sowing $\left(\mathrm{kg} \mathrm{ha}^{-1}\right)$ & - \\
$\mathrm{K}_{2} \mathrm{O}$ & -- & -- & -- & - \\
\hline
\end{tabular}

$\mathrm{N}=$ ammonium sulfate $(18 \% \mathrm{~N}), \mathrm{P}_{2} \mathrm{O}_{5}=$ simple superphosphate $\left(18 \% \mathrm{P}_{2} \mathrm{O}_{5}\right)$ e $\mathrm{K}=$ potassium chloride $\left(60 \% \mathrm{~K}_{2} \mathrm{O}\right)$.

Sixty days after sowing, soil samples were collected at 0-20 cm depth. In each plot 10 simple samples were collected, which were mixed to form the composite sample representing the plot. Soil samples were air dried, sieved to 2 $\mathrm{mm}$ and analyzed for soil chemical properties $\left(\mathrm{pH}\right.$ in $\mathrm{CaCl}_{2} 0.05 \mathrm{~mol} \mathrm{~L}^{-1}$, organic matter, phosphorus extracted by resin, potassium, calcium and magnesium extracted by $\mathrm{KCl}, \mathrm{H}+\mathrm{Al}$ ) as described in Raij et al. [10]. Sum of bases, cation change capacity (CEC) and bases saturation (V\%) were calculated with the data of $\mathrm{K}, \mathrm{Ca}, \mathrm{H}+\mathrm{Al}$.

To evaluate grain yield, cobs were collected from plants in the center line of each plot after 128 days after sowing. The cobs were husked, left to air and shade to complete the drying and thrashed. Grains were dried in a stove with forced air circulation at $60-70^{\circ} \mathrm{C}$. Grain yield was expressed with $13 \%$ moisture [11].

The data were submitted to statistical analysis by the Tukey test at 5\% probability (in the figures, letters followed by the same letter are not different in 
the test). We also made a group analysis for the comparison of the two experimental areas.

\section{Results and discussion}

The $\mathrm{pH}$ of the two soils ranged from 4.4. to 4.8 and was not affected by the treatments. In the rate $10 \mathrm{t} \mathrm{ha}^{-1} \mathrm{SS}$ the $\mathrm{pH}$ of the soil TE was higher than the $\mathrm{pH}$ of the soil TH, fig. 1. The soil $\mathrm{pH}$ evaluation is very important for the knowledge of trace elements solubility and mobility in the soil profile. When $\mathrm{pH}$ increases, $\mathrm{OH}$ groups from the organic matter, $\mathrm{Al}$ and $\mathrm{Fe}$ oxides are ionized causing an increase in negative charges, increasing the soil adsorption capacity [12].

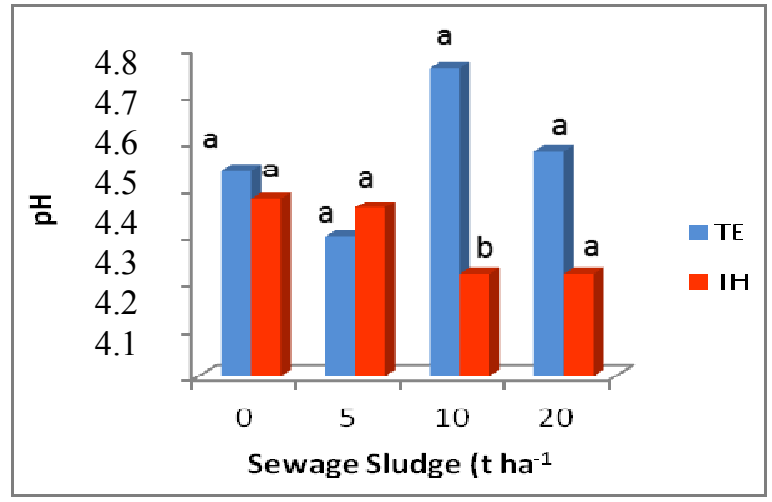

Figure 1: Values of $\mathrm{pH}$ in soils Typic Eutrorthox (TE) and Typic Haplorthox (TH) treated with rates of sewage sludge for sixteen consecutive years.

The concentration of organic matter was in the range of $25.8-26.4 \mathrm{~g} \mathrm{dm}^{-3}$ in the soil TE and 18.4-21.8 $\mathrm{g} \mathrm{dm}^{-3}$ in the soil TH and was not affected by the treatments, as shown in tables 2 and 3. This difference between the soils was expected since TE is clayey (clay $=61 \%$ ), and TH is sandy (clay $=22 \%$ ). When comparing the concentration of organic matter in the two soils, it was higher in TE for all the rates of SS, fig. 2. Some authors have observed that it is possible to increase soil organic matter for a long period of time, only for high doses of SS [13].

Phosphorus extracted by resin ranged from 45.2 to $67.8 \mathrm{mg} \mathrm{dm}^{-3}$ in the soil $\mathrm{TE}$ and from 41.8 to $79.8 \mathrm{mg} \mathrm{dm}^{-3}$ in the soil TH and no effect was detected for rates of SS sludge or for the soil type, tables 2 and 3, fig. 3. In an experiment with sewage sludge [9], an increase in soil $\mathrm{P}$ was observed, and it was concluded that the residue is an important source of $\mathrm{P}$ to soils.

Soil K was affected by the treatments only in the soil TE and in the rate $10 \mathrm{t}$ $\mathrm{ha}^{-1}$, which differed from the control, tables 2 and 3. Differences between soils were observed in all treatments, fig. 4. In the control, the soil TH presented more $\mathrm{K}$ than the soil TE, but in the treatments with SS, K concentration was higher in 
the soil TE. Fig. 5 shows a closely relation between soil $\mathrm{K}$ and organic matter in the soil TE.

Table 2: Chemical characteristics of a Typic Eutrorthox (TE) treated with rates of sewage sludge for sixteen consecutive years.

\begin{tabular}{|c|c|c|c|c|c|c|c|c|c|c|}
\hline \multirow[t]{2}{*}{ Treatments } & \multirow{2}{*}{$\begin{array}{c}\mathbf{P} \\
\mathrm{mg} \mathrm{dm}^{-3}\end{array}$} & \multirow{2}{*}{$\frac{\text { OM }}{\mathrm{g} \mathrm{dm}^{-3}}$} & \multirow[t]{2}{*}{$\mathrm{pH}$} & $\mathbf{K}$ & $\mathrm{Ca}$ & $\mathrm{Mg}$ & $\mathbf{H}+\mathbf{A l}$ & SB & CEC & \multirow{2}{*}{$\begin{array}{l}\mathbf{V} \\
\%\end{array}$} \\
\hline & & & & \multicolumn{6}{|c|}{ - $\mathrm{mmol}_{\mathrm{c}} \mathrm{dm}^{-3}$} & \\
\hline 0 tha $^{-1}$ & $45.2 \mathrm{a}$ & $25.8 \mathrm{a}$ & $4.5 \mathrm{a}$ & $3.9 \mathrm{~b}$ & $16.2 \mathrm{a}$ & $5.2 \mathrm{a}$ & $43.6 \mathrm{a}$ & $25.3 \mathrm{a}$ & $68.9 \mathrm{a}$ & $37.1 \mathrm{a}$ \\
\hline 5 tha $^{-1}$ & $61.6 \mathrm{a}$ & $26.2 \mathrm{a}$ & $4.4 \mathrm{a}$ & $5.1 \mathrm{ab}$ & $16.4 \mathrm{a}$ & $5.2 \mathrm{a}$ & $52.8 \mathrm{a}$ & $26.7 \mathrm{a}$ & $79.5 \mathrm{a}$ & $34.0 \mathrm{a}$ \\
\hline $10 \mathrm{tha}^{-1}$ & $67.0 \mathrm{a}$ & $26.4 \mathrm{a}$ & $4.8 \mathrm{a}$ & $5.7 \mathrm{a}$ & $19.0 \mathrm{a}$ & $6.2 \mathrm{a}$ & $43.2 \mathrm{a}$ & $30.9 \mathrm{a}$ & $74.1 \mathrm{a}$ & $41.6 \mathrm{a}$ \\
\hline $20 \mathrm{tha}^{-1}$ & $67.8 \mathrm{a}$ & $26.0 \mathrm{a}$ & $4.6 \mathrm{a}$ & $4.4 \mathrm{ab}$ & $19.0 \mathrm{a}$ & $5.8 \mathrm{a}$ & $45.2 \mathrm{a}$ & $29.2 \mathrm{a}$ & $74.4 \mathrm{a}$ & $40.1 \mathrm{a}$ \\
\hline
\end{tabular}

$\mathrm{OM}=$ organic matter, $\mathrm{CEC}=$ cation exchange capacity, $\mathrm{SB}=$ sum of bases, $\mathrm{V}=$ basis saturation . Means followed by the same letters are not different by the Tukey test at $5 \%$.

Table 3: Chemical characteristics of a Typic Haplorthox (TH) treated with rates of sewage sludge for sixteen consecutive years.

\begin{tabular}{|c|c|c|c|c|c|c|c|c|c|c|}
\hline \multirow[t]{2}{*}{ Treatments } & \multirow{2}{*}{$\begin{array}{c}\mathbf{P} \\
\mathrm{mg} \mathrm{dm^{-3 }}\end{array}$} & \multirow{2}{*}{$\begin{array}{c}\text { OM } \\
\mathrm{g} \mathrm{dm}^{-3}\end{array}$} & \multirow[t]{2}{*}{ pH } & $\mathbf{K}$ & $\mathbf{C a}$ & Mg & $\mathbf{H}+\mathbf{A l}$ & SB & CTC & \multirow{2}{*}{$\begin{array}{l}\text { V } \\
\%\end{array}$} \\
\hline & & & & \multicolumn{6}{|c|}{ - } & \\
\hline $0 \mathrm{tha}^{-1}$ & $41.8 \mathrm{a}$ & $18.4 \mathrm{a}$ & $4.5 \mathrm{a}$ & $5.8 \mathrm{a}$ & $9.2 \mathrm{a}$ & $2.2 \mathrm{a}$ & $31.4 \mathrm{a}$ & $17.2 \mathrm{a}$ & $48.6 \mathrm{a}$ & $36.0 \mathrm{a}$ \\
\hline $5 \mathrm{tha}^{-1}$ & $63.2 \mathrm{a}$ & $19.6 \mathrm{a}$ & $4.5 \mathrm{a}$ & $3.7 \mathrm{a}$ & $11.6 \mathrm{a}$ & $3.2 \mathrm{a}$ & $37.0 \mathrm{a}$ & $18.5 \mathrm{a}$ & $55.5 \mathrm{a}$ & $34.9 \mathrm{a}$ \\
\hline $10 \mathrm{tha}^{-1}$ & $79.6 \mathrm{a}$ & $21.6 \mathrm{a}$ & $4.3 \mathrm{a}$ & $3.6 \mathrm{a}$ & $12.6 \mathrm{a}$ & $3.0 \mathrm{a}$ & $38.4 \mathrm{a}$ & $19.2 \mathrm{a}$ & $57.6 \mathrm{a}$ & $33.6 \mathrm{a}$ \\
\hline $20 \mathrm{tha}^{-1}$ & $79.8 \mathrm{a}$ & $21.8 \mathrm{a}$ & $4.3 \mathrm{a}$ & $3.0 \mathrm{a}$ & $11.0 \mathrm{a}$ & $2.4 \mathrm{a}$ & $40.6 \mathrm{a}$ & $16.4 \mathrm{a}$ & $57.0 \mathrm{a}$ & $28.6 \mathrm{a}$ \\
\hline
\end{tabular}

$\mathrm{OM}=$ organic matter, $\mathrm{CEC}=$ cation exchange capacity, $\mathrm{SB}=$ sum of bases, $\mathrm{V}=$ basis saturation. Means followed by the same letters are not different by the Tukey test at $5 \%$.

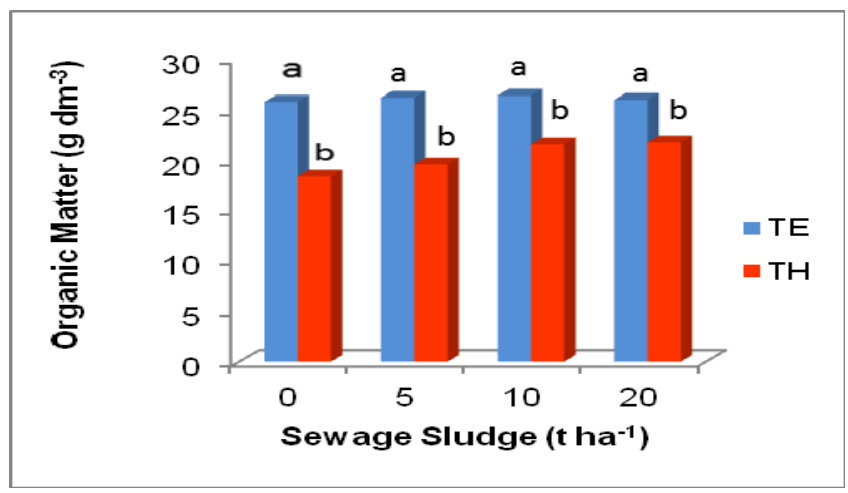

Figure 2: Values of organic matter in Typic Eutrorthox (TE) and Typic Haplorthox $(\mathrm{TH})$ treated with rates of sewage sludge for sixteen consecutive years. 


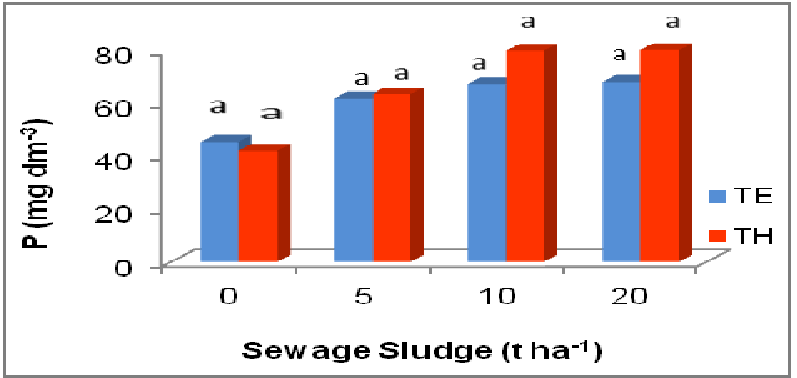

Figure 3: Values of phosphorus in Typic Eutrorthox (TE) and Typic Haplorthox $(\mathrm{TH})$ treated with rates of sewage sludge for sixteen consecutive years.

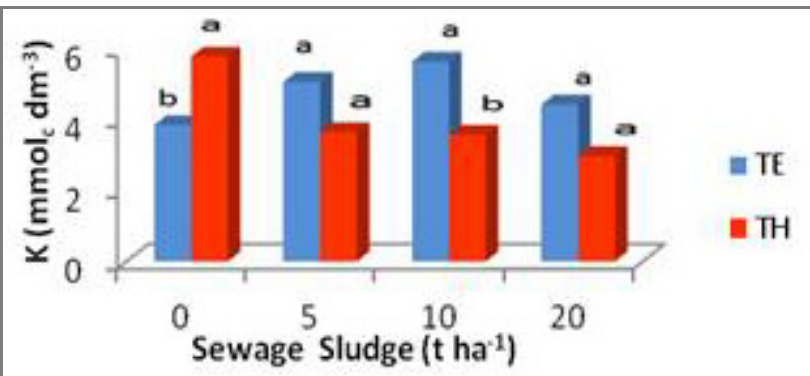

Figure 4: Values of potassium in Typic Eutrorthox (TE) and Typic Haplorthox (TH) treated with rates of sewage sludge for sixteen consecutive years.

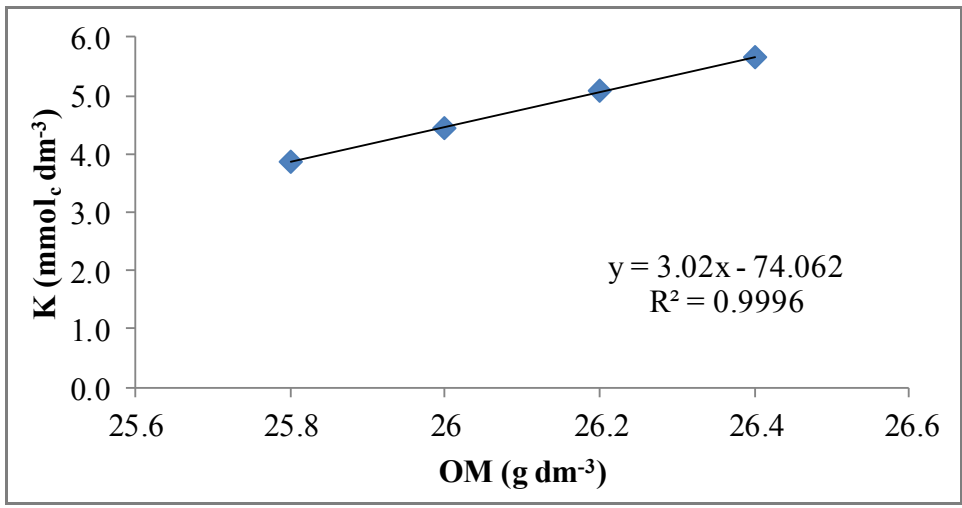

Figure 5: Relation between potassium and organic matter in the soil Typic Eutrorthox (TE) treated with rates of sewage sludge for sixteen consecutive years. 
Depending on the processing of the wastewater treatment in the WTS, the content of K in SS may be very low, because this element is very soluble and stays in the water fraction during the processing, and so it is removed from the SS [14].

Calcium concentration in soil has no difference between the treatments in both the soils, tables 2 and 3. It ranged from 16.2 to $19.0 \mathrm{mmol}_{\mathrm{c}} \mathrm{dm}^{-3}$ in the TE and from 9.2 to $11.0 \mathrm{mmol}_{\mathrm{c}} \mathrm{dm}^{-3}$ in the $\mathrm{TH}$, values considered high in terms of soil fertility [15]. In all the treatments, Ca concentration was higher in the soil TE, fig. 6. Some authors have observed an increase of $\mathrm{Ca}$ concentration in soil by using SS, but they used a residue treated with lime [16-18].

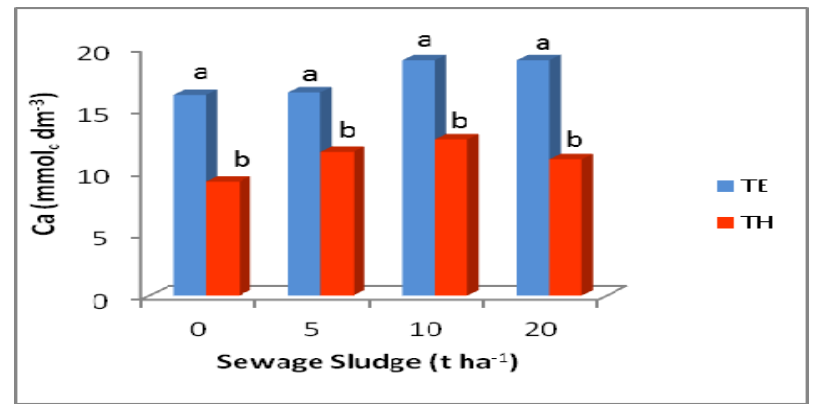

Figure 6: Values of calcium in Typic Eutrorthox (TE) and Typic Haplorthox (TH) treated with rates of sewage sludge for sixteen consecutive years.

The values obtained for magnesium also were not affected by the treatments in the two soils, tables 2 and 3 . Soil $\mathrm{Mg}$ concentration ranged from 5.2 to 5.8 $\mathrm{mmol}_{\mathrm{c}} \mathrm{dm}^{-3}$ in the soil TE and from 2.2 to $3.2 \mathrm{mmol}_{\mathrm{c}} \mathrm{dm}^{-3}$ in the soil TH, fig. 7 . According to [4], studies have shown that the addition of SS increases the concentration of $\mathrm{Mg}$ in the leaves of sugarcane, maize and sorghum.

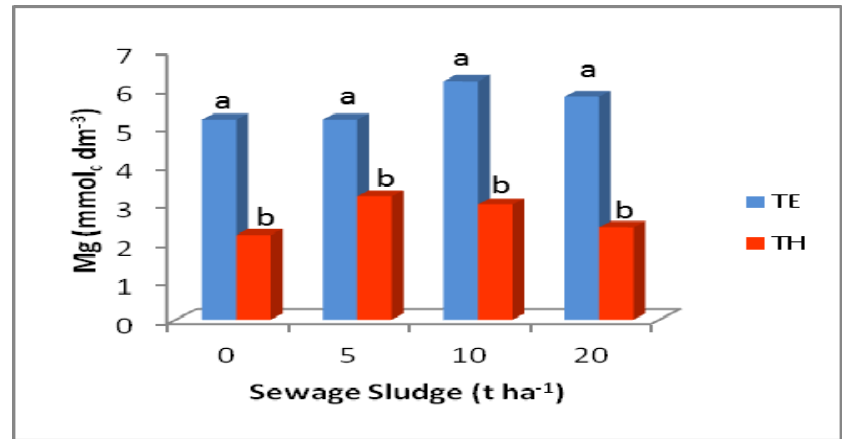

Figure 7: Values of magnesium in Typic Eutrorthox (TE) and Typic Haplorthox (TH) treated with rates of sewage sludge for sixteen consecutive years. 
The data obtained for potential acidity $(\mathrm{H}+\mathrm{Al})$, sum of bases and bases saturation were also not affected by the treatments, tables 2 and 3. Considering the attribute $\mathrm{H}+\mathrm{Al}$, in the rate $5 \mathrm{tha}^{-1} \mathrm{SS}$ it was higher in the soil TE compared to the soil TH, fig. 8. For the sum of bases in all the treatments the values were higher in the soil TE, fig. 9, while in the case of bases saturation only in the rate $20 \mathrm{t} \mathrm{ha}^{-1} \mathrm{SS}$ were the values in the soil TE higher, fig. 11. The bases saturation ( $\mathrm{V} \%$ ) was lower than $70 \%$, and is considered the ideal value for maize crop and this may negatively influence the grain production.

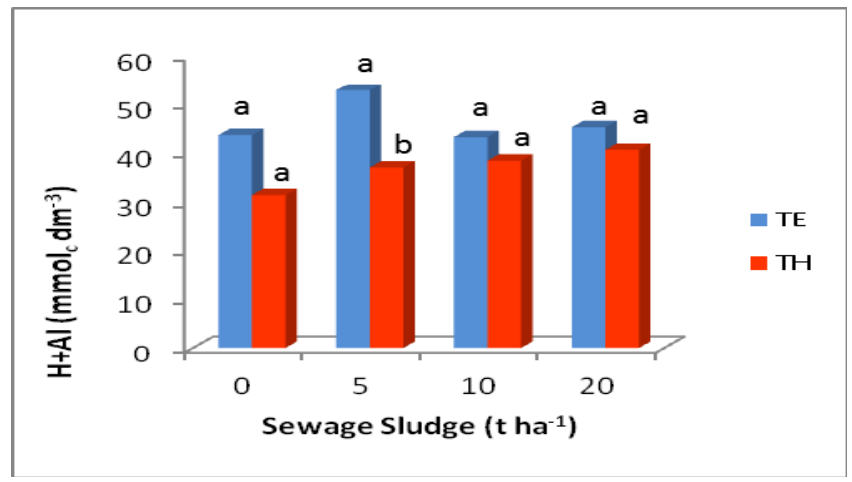

Figure 8: Potential acidity $(\mathrm{H}+\mathrm{Al})$ in Typic Eutrorthox (TE) and Typic Haplorthox $(\mathrm{TH})$ treated with rates of sewage sludge for sixteen consecutive years.

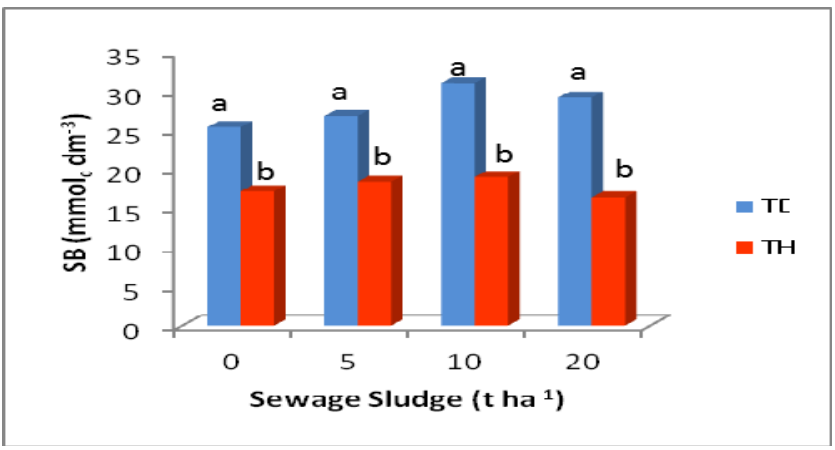

Figure 9: $\quad$ Sum of bases (SB) in Typic Eutrorthox (TE) and Typic Haplorthox (TH) treated with rates of sewage sludge for sixteen consecutive years.

The cation exchange capacity (CEC), estimated by the sum of $\mathrm{K}, \mathrm{Ca}, \mathrm{Mg}$ and $\mathrm{H}+\mathrm{Al}$, was not affected by the treatments and ranged from 68.9 to $79.4 \mathrm{mmol}_{\mathrm{c}}$ $\mathrm{dm}^{-3}$ in soil TE and from 48.6 to $57.0 \mathrm{mmol}_{\mathrm{c}} \mathrm{dm}^{-3}$ in the soil $\mathrm{TH}$, as shown in 
tables 2 and 3. In all the treatments the CEC was higher in the soil TE as compared to the soil $\mathrm{TH}$, fig. 10.

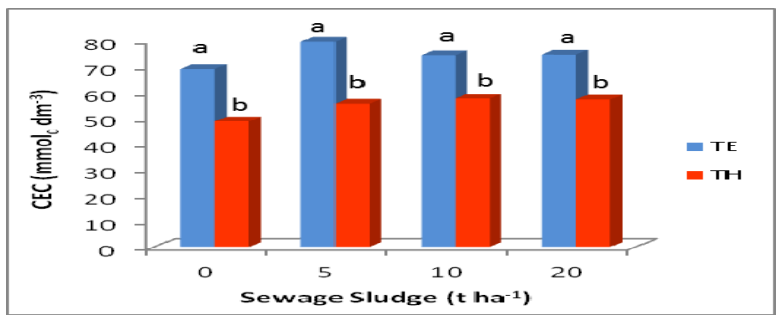

Figure 10: Values of cation exchange capacity (CEC) in Typic Eutrorthox (TE) and Typic Haplorthox $(\mathrm{TH})$ treated with rates of sewage sludge for sixteen consecutive years.

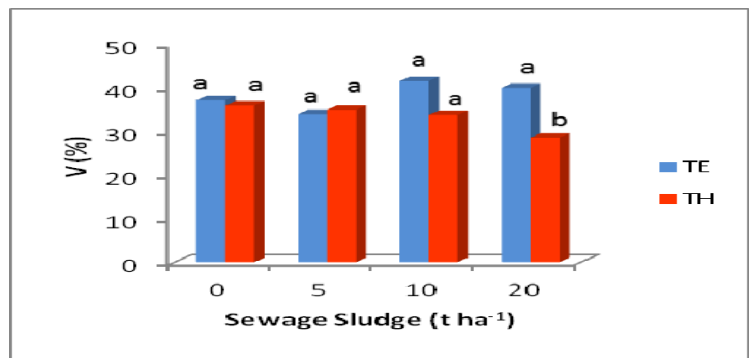

Figure 11: Base sauration (V) in Typic Eutrorthox (TE) and Typic Haplorthox (TH) treated with rates of sewage sludge for sixteen consecutive years.

The maize grain yield was not significantly different between the soils and the treatments, fig. 12. For both the soils, a rate of $5 \mathrm{t} \mathrm{ha}^{-1} \mathrm{SS}$, dry weight basis, plus $\mathrm{K}$ produced the same as the mineral fertilization.

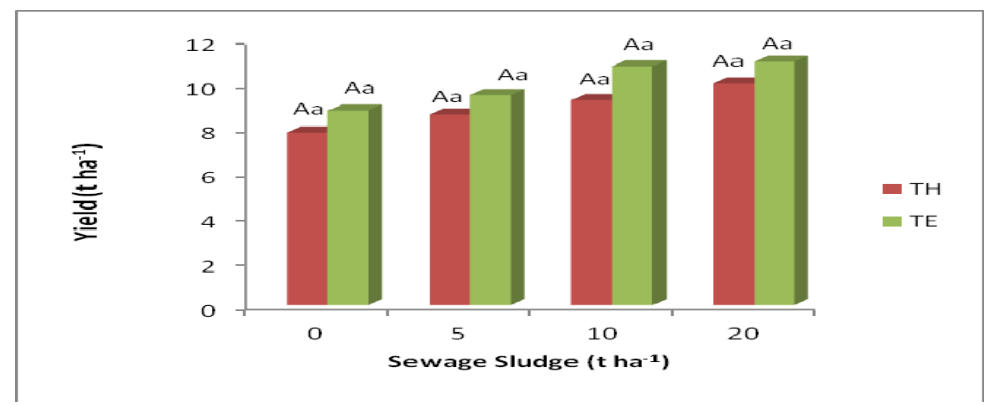

Figure 12: Corn yield in Typic Eutrorthox (TE) and Typic Haplorthox (TH) treated with rates of sewage sludge for sixteen consecutive years. 


\section{Conclusion}

Amending the soils Typic Eutrorthox and Typic Haplorthox with $10 \mathrm{t} \mathrm{ha}^{-1} \mathrm{SS}$ in the sixteen consecutive years increased soil potassium concentration. The other soil characteristics evaluated $(\mathrm{pH}$, organic matter, $\mathrm{K}, \mathrm{Ca}, \mathrm{Mg}$, potential acidity, CEC, bases saturation and sum of bases) were not affected by SS amendment.

The amount of $\mathrm{K}$ correlated linearly and positively with the organic matter concentration in the soil Typic Eutrorthox.

Maize grain yield was not affected in the sixteenth year of sewage sludge application in rates of 5, 10 and $20 \mathrm{tha}^{-1}$, dry weight basis.

The soil Typic Eutrorthox tended to present better chemical properties than the soil Typic Haplorthox.

After sixteen years of annual application of rates of sewage sludge the bases saturation is below the recommended for maize cropping $(70 \%)$.

Maize fertilized with $5 \mathrm{t} \mathrm{ha}^{-1}$ sewage sludge, dry weight basis, plus $\mathrm{K}$, produced the same as that of mineral fertilization.

\section{Acknowledgement}

The authors thank Conselho Nacional de Desenvolvimento Científico e Tecnológico (CNPq) for providing scholarships.

\section{References}

[1] Fernandes. F.; Andreoli. C. V. Manual técnico para utilização agrícola do lodo de esgoto no Paraná. Curitiba: SANEPAR. 1997. p. 96.

[2] Melo. W.J.; Marques. M.O.; Melo. V.P. O uso agrícola do biossólido e as propriedades do solo. In: Tsutiya. M.T.; Comparini. J.B.; Alem Sobrinho. P.; Hespanhol. I.; Carvalho. P.C.T.; Melfi. A.J; Melo. W.J.; Marques. M.O. (Eds). Biossólidos na agricultura. São Paulo: SABESP. 2001. pp. 289-363.

[3] Sobrinho. P. A. Tratamento de esgoto e geração de lodo. In: TSUTIYA. M. T. Biossólido na agricultura. São Paulo: SABESP. 2001. pp. 7-40.

[4] Melo. W.J.; Marques. M.O. Potencial do lodo de esgoto como fonte de nutrientes para as plantas. In: BETIOL. W.; CAMARGO. O. A. (Eds.). Impacto ambiental do uso agrícola do lodo de esgoto. Jaguariúna: EMBRAPA Meio Ambiente. 2000. p. 312.

[5] Bettiol. W.; Camargo. O.A. Impacto ambiental do uso agrícola do lodo de esgoto. Jaguariúna: Embrapa Meio Ambiente. 2000. p. 312.

[6] Silveira. M.L.A.; Alleoni. L.R.F.; Guilherme. L.R.G. Biosolids and heavy metals in soils. Scientia Agricola. 60:793-806. 2003.

[7] Andreoli. C.V. Resíduos sólidos do saneamento: Processamento. reciclagem e disposição final. Rio de Janeiro: Rima. ABES. 2001. p. 282.

[8] Silva. J.E.; Resck. D.V.S.; Sharma. R.D. Alternativa para o biossólido produzido no Distrito Federal. 1 Efeito na produção de milho e na adição 
de metais pesados em Latossolo no cerrado. Revista Brasileira de Ciência do Solo. 26:487-495. 2002.

[9] Melo. W.J; Aguiar. P. S.; Melo. G.M.P; Melo. V.P. "Nickel in a tropical soil treated with sewage sludge and cropped with maize in a long-term field study." Soil Biology and Biochemistry. .39. pp. 1341-1347. 2007.

[10] Raij. B. Van; Andrade. J. C.; Cantarella. H.; Quaggio. J. A. Análise química para avaliação da fertilidade de solos tropicais. Campinas: Instituto Agronômico. 2001. p. 285.

[11] Empresa Brasileira de Pesquisa Agropecuária - Embrapa. Tecnologias de produção de soja - região central do Brasil. Londrina: Embrapa Soja, Embrapa Cerrados, Embrapa Agropecuária Oeste, 2007. p. 225.

[12] Alleoni. L.R.F.; Iglesias. C.S.M.; Mello. S.C.; Camargo. O.A.; Casagrande. J.C. \& Lavorenti. N.A. "Atributos do solo relacionados à adsorção de cádmio e cobre em solos tropicais". Acta Science Agronomy. 27:729. 2005.

[13] Santos. L.M.; Milori. D.M.B.P.; Simões. M.L.; Silva. W.I.L.; PereiraFilho. E.R.; Melo. W.J. \& Martin-Neto. L. "Characterization by Fluorescence of Organic Matter from Oxisols under Sewage Sludge Applications”. Soil Science Society American Journal. 74:94. 2010.

[14] Tsutiya. M.T. Alternativas de disposição final de biossólidos gerados em estações de tratamento de esgotos. In: Bettiol. W.; Camargo. O.A. Impacto ambiental do uso agrícola do lodo de esgoto. Jaguariúna: EMBRAPA. 2000. 4:69-106.

[15] Raij. B. van; Cantarella. H.; Quaggio. J.A. \& Furlani. A.M.C. Recomendação de adubação e calagem para o Estado de São Paulo. 2. ed. Campinas. Instituto Agronômico/Fundação IAC. 1996. p. 285. (Boletim Técnico. 100).

[16] Melo, W. J.; Marques, M. O.; Melo, V. P. O uso agrícola do biossólido e as propriedades do solo. In: TSUTIYA, M. T. et al. Biossólido na agricultura. São Paulo: Sabesp, 2001. pp. 289-363.

[17] Oliveira, F. C. "Lodo de esgoto como fonte de macronutrientes para a cultura do sorgo granífero.” Scientia Agricola, Piracicaba, 52, 2:360-367, 1995.

[18] Nascimento, D. A. “Alterações químicas em solos e crescimento de milho e feijoeiro após aplicação de lodo de esgoto". Revista Brasileira de Ciência do Solo, Viçosa, v. 28, n. 2, pp. 385-392, 2004. 